\title{
Urban versus Rural? Conflict Lines in Land Use Disputes in the Urban-Rural Fringe Region of Schwerin, Germany
}

\author{
Meike Fienitz * and Rosemarie Siebert
}

check for

updates

Citation: Fienitz, M.; Siebert, R.

Urban versus Rural? Conflict Lines in

Land Use Disputes in the

Urban-Rural Fringe Region of

Schwerin, Germany. Land 2021, 10,

726. https://doi.org/10.3390/

land10070726

Academic Editors:

Ileana Pătru-Stupariu and

Christine Fürst

Received: 26 May 2021

Accepted: 8 July 2021

Published: 10 July 2021

Publisher's Note: MDPI stays neutral with regard to jurisdictional claims in published maps and institutional affiliations.

Copyright: (c) 2021 by the authors. Licensee MDPI, Basel, Switzerland. This article is an open access article distributed under the terms and conditions of the Creative Commons Attribution (CC BY) license (https:// creativecommons.org/licenses/by/ $4.0 /)$
Leibniz Centre for Agricultural Landscape Research (ZALF), Eberswalder Straße 84, 15374 Müncheberg, Germany; rsiebert@zalf.de

* Correspondence: meike.fienitz@zalf.de
Abstract: Land use conflicts can present major obstacles to sustainable land management. An accurate understanding of their actor constellations and conflict lines is therefore crucial in developing tools for successful landscape governance. In this context, actors from cities and actors from rural areas are often seen as typical opponents. Hence, the objective of this paper is to analyze the extent to which empirical conflict lines indeed run between urban and rural actors. We applied qualitative text analysis to examine 124 land use conflicts in the urban-rural fringe of Schwerin, Germany, which were identified through semistructured interviews with key land use actors in the region. Results showed that actors from the city and the rural fringe were on opposing sides in almost half of the conflicts. However, they were also frequently in conflict among themselves, and many actor constellations involved actors from other regions or administrative levels. In conclusion, the narrative of the urban-rural dichotomy appears in the empirical data but does not appropriately convey the complexity of the actual conflict lines. The findings of this paper therefore emphasize that it is important to empirically identify the actor constellations in land use conflicts rather than rely on preconceived ideas about typical conflict lines.

Keywords: urban-rural conflict; urban-rural dichotomy; land use conflict; conflict parties; spatial affiliation; actor constellation; urban-rural development; balanced land use

\section{Introduction}

Landscapes are subject to diverse pressures and demands (i.e., [1-4]) that often lead to conflicts among land use actors. In the literature, these are commonly referred to as land use conflicts (i.e., von der Dunk et al.: "a land-use conflict occurs whenever land-use stakeholders (=conflict parties) have incompatible interests related to certain land-use units (=geographical component)." (p. 149, [5])). Land use conflicts can be serious obstacles to sustainable land management [6-8] and are therefore an important factor to consider in landscape governance. Hence, a thorough understanding of land use conflicts is needed; only with accurate knowledge of the conflict parties and their positions and interests can we hope to balance manifold land use demands.

In this context, actors from cities and actors in rural areas are often seen as having fundamentally contradicting interests regarding land use, and thus typical opponents in land use conflicts. City dwellers are said to demand rural land uses such as food or energy production, nature conservation, or resource extraction, while inhabitants of rural areas supposedly lament the negative externalities or consequences of these land uses. This narrative is prominent within general societal discourse and mass media. For example, Deutschlandfunk reported the diverging interests of conservationists and farmers under the headline "Conflict between City and Countryside" [9]. In contrast, Berlin's daily newspaper Tagesspiegel criticized debates about the alleged political neglect of rural areas, warning that "city and countryside must not be pitted against each other" [10]. However, this narrative is also reflected in scientific discourse and studies. For example, there is recent literature on urban-rural conflicts in China (i.e., Yu et al. on risk factors [11] and Yu 
et al. on causes [12] of urban-rural conflict, Shan et al. on risk management in urban-rural conflict [13]), and urban-rural conflicts have been part of water conflicts in India [14] and Morocco [15], as well as in environmental policy in the United States [16] and urbanization expansion in Ethiopia [17].

However, concluding from these studies that the land use interests of actors in urban and rural areas are inherently dichotomous might be too hasty a generalization. First, rural actors depend on rural land uses for resource extraction, nature conservation, and food and energy production, just as urban actors do. Moreover, both urban and rural actors are diverse groups with manifold land use interests [18-20]. In this context, the utility of the very concepts of urban and rural areas has been questioned [21,22]. Therefore, a closer look at the conflict lines (understood here as imaginary lines that demarcate the positions of opposing conflict parties) across a wider range of land use conflicts might be worthwhile to improve our understanding of the actor constellations that can be expected and thus to allow us to develop suitable tools for balanced landscape governance.

Identifying the actors and coalitions involved in a conflict and their positions is generally considered an important step in conflict analysis (i.e., [23-26]). In line with this, several authors have addressed the question of who is involved in land use conflicts in various contexts. For example, Darkoh and Mbaiwa grouped land use conflict actors in Botswana as traditional and emerging stakeholders, and found that these groups were in conflict with each other but also among themselves [27]. Similarly, in their analysis of land use conflicts in Nigeria, Abegunde et al. differentiated between farmer-farmer and farmer-pastoralist conflicts [28]. Steinhäußer et al. classified land use conflicts in Germany according to the land use sectors (settlement/transportation, agriculture, forestry, conservation) that were in conflict with each other or among themselves [29]. Furthermore, in their analysis of conflicts over farmland uses in the Greater Paris Region, Darly and Torre found four main conflict lines running between different levels of authority, as well as between authorities and associations or private commercial organizations [30]. Finally, Hjalager provided a detailed analysis of conflict lines in approximately 200 land use conflicts related to Danish coastal tourism. She identified categories of protesters and offenders such as "municipalities" and "holiday home owners" and even determined the most frequent winners and losers among these actor groups [31].

While these works provide important insights regarding the actors and sectors involved in land use conflicts, no studies thus far have analyzed to what extent conflict lines run between urban and rural areas. The objective of this paper is therefore to empirically examine the spatial patterns of conflict lines in land use conflicts to determine whether an urban-rural dichotomy is reflected in the actual lines of these conflicts. Analyzing the land use conflicts that occur in urban-rural fringe regions is likely the best way to obtain insights into this topic, as these are the areas where, for reasons of spatial proximity, conflicts between rural and urban actors are expected to occur most frequently [5]. Therefore, this paper asks: To what extent do the conflict lines in urban-rural fringe regions run between urban and rural actors? This paper thus aims to advance the debate about the urban-rural dichotomy by providing an improved understanding of empirical conflict lines. For the reasons outlined above, it is hypothesized that the idea of a dichotomy between rural and urban areas might be too simplistic in the context of land use conflicts.

\section{Materials and Methods}

To answer the research question, 124 land use conflicts in the urban-rural fringe region of Schwerin, Germany, and in the adjacent rural areas, were analyzed. This section describes the study region and the methods applied.

\subsection{Study Region}

Schwerin is a city of just under 100,000 inhabitants in Northern Germany, located in one of the least populated regions of the country. Its fringe is shaped by a comparatively rapid transition from urban to rural; this spatial proximity was considered ideal 
for the study of urban-rural conflicts. After German reunification in 1990, Schwerin saw a considerable loss of inhabitants, while the communities on its outskirts experienced a period of growth. Although the city is currently growing slowly, there is still competition between the city and the surrounding communities. Agriculture plays a central role in the region outside the fringe of Schwerin but is also important in many fringe communities. As there are major lakes within and near the city, tourism and outdoor recreation also play a role in the region but have repeatedly come into conflict with nature conservation efforts. Finally, both within the fringe and beyond it, conflicts related to energy infrastructure, most importantly biogas plants and wind turbines, are becoming increasingly common.

As the concepts "urban" and "rural" lack coherent definitions [32], this study relied on administrative borders to demarcate categories for the analysis. Schwerin has an official fringe region consisting of 14 communities, 13 of which directly border the city (Fringe communities are defined by the government of Mecklenburg-Western Pomerania as those communities that have a direct border with a city, as well as communities in the second or third belt that have strong spatial interlinkages with a city (i.e., a high number of commuters, an industrial area or residential area serving the city, or a suburban character)). As the border between the fringe and the city is the exact location where rural and urban areas meet, most urban-rural conflict was expected to occur there. Hence, a special focus was placed on the official fringe during the data collection, and this area was analyzed separately from the remaining rural areas located farther away from the city. Communities outside this official fringe but within the two administrative districts that flank the city of Schwerin were placed in a category called "rural areas outside the fringe", and they were also included in our analysis. Thus, the "rural" category from the urban-rural dichotomy narrative was broken down into two subcategories: the fringe area and the rural communities outside this fringe. Figure 1 depicts the study region, including the city of Schwerin, its fringe, and the rural areas outside the fringe; Figure 2 shows the location of the study region within Germany.

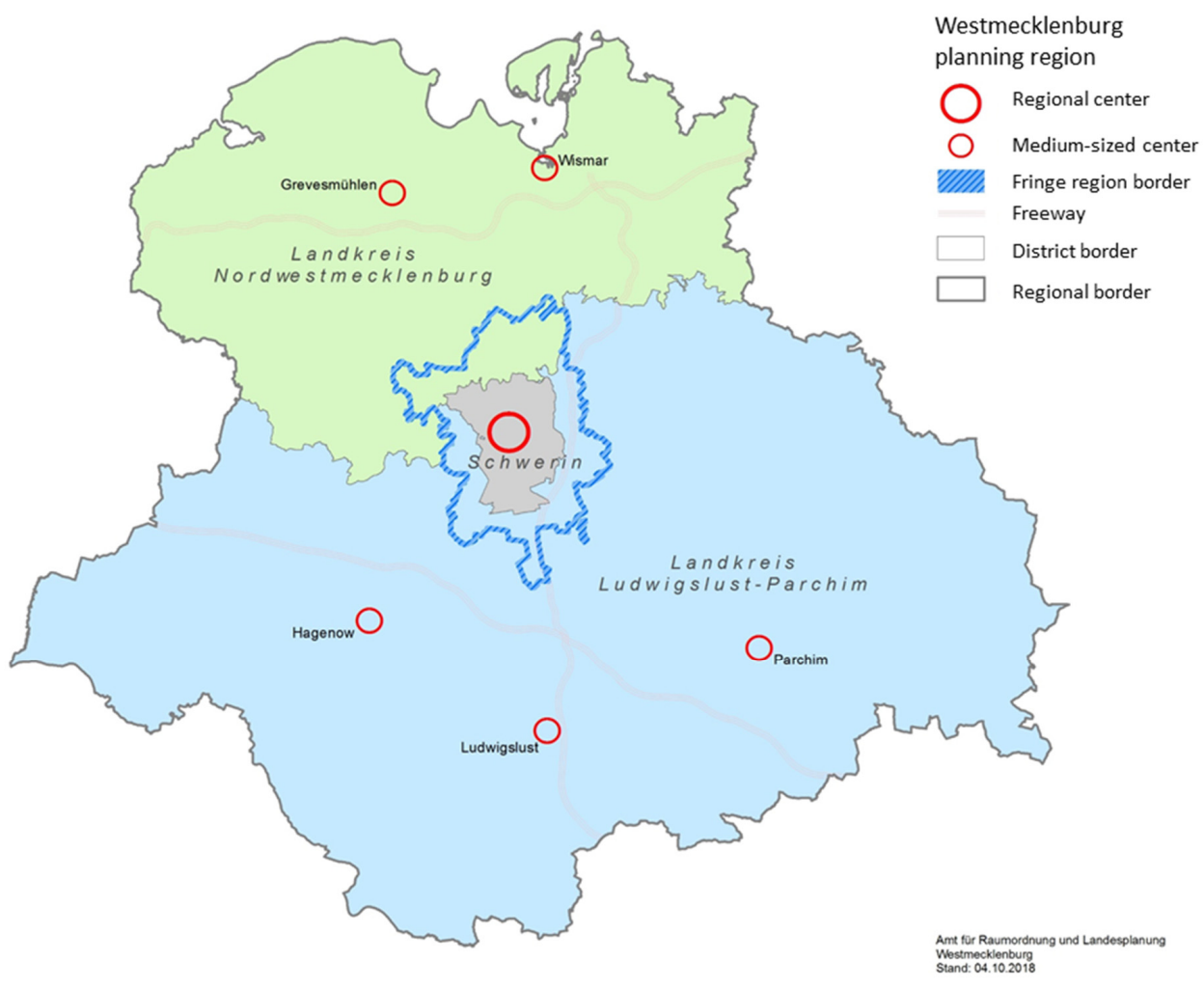

Figure 1. City of Schwerin (gray area), official fringe region (marked by the blue border), Nordwestmecklenburg (green), and Ludwigslust-Parchim (blue) administrative districts; copyright Amt für Raumordnung und Landesplanung Westmecklenburg. 


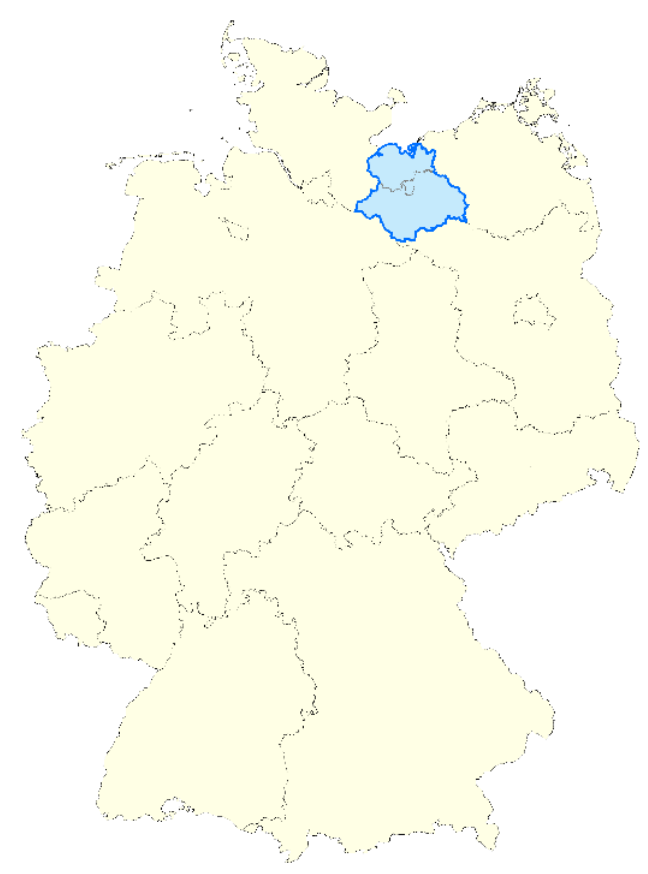

Figure 2. Location of the study region within Germany, copyright Amt für Raumordnung und Landesplanung Westmecklenburg.

\subsection{Semistructured Qualitative Interviews with Key Land Use Actors}

To obtain a comprehensive picture of the land use conflicts that occur in the study region, semistructured, problem-focused interviews [33] were conducted with key land use actors in the region. These actors served as experts who knew the region and its conflicts well. While scholars have gathered data on land use conflicts using a number of different sources, such as local media, litigation rulings, and geographic information systems (GIS) (i.e., $[31,34,35])$, expert interviews were chosen because they promised to provide the most comprehensive overview of a diverse range of land use conflicts, including conflicts that may not (yet) have been covered by the media or negotiated in court. Moreover, in their extensive discussion of empirical methods for studying land use conflicts, Torre et al. found expert interviews particularly useful for learning about the alliances and oppositions involved in said conflicts [36]. Torre et al. however warn that interview partners may forget or omit some conflicts; thus, at least two interview partners for each land use field were selected. Many interviewees further made an effort to ensure that their reports were as complete as possible by consulting colleagues or bringing them to the interview or by providing additional materials, such as reports or plans. While a complete overview of land use conflicts in one region is probably unattainable, this method likely covered all major and many minor conflicts in the region.

To select interview partners, a stakeholder analysis [23] was conducted, and project partners from local land use practice then identified those actors that they considered to be critical for all the different land use aspects of the region. As the study placed a special emphasis on the fringe, actors' expertise regarding land use issues within the fringe region was a particularly important selection criterion, although most actors were knowledgeable on issues well beyond the direct fringe. To ensure the completeness of the inquiry, this process was supplemented with a snowball system, and each interviewee was asked to name any other actors they considered important with regard to local land use questions. This resulted in 32 interviews with mayors and other political actors, local agencies, interest groups, nongovernmental organizations (NGOs), local boards, and businesses. Some actors specifically represented the agriculture, water management, environmental conservation, and forestry sectors, but most were cross-sectoral actors. 
The interviews were conducted face to face between June and November 2019. The main aim was to gain a broad overview of land use conflicts in the study region. Then, further questions were developed to collect more detailed information on the conflicts, such as which actors were involved, what their positions and interests were, and the conflicts' histories and evolution (see Document S1: Interview guideline in the Supplementary Materials). On the basis of this information, the conflict lines were determined during the analysis process described in the next section.

\subsection{Qualitative Text Analysis}

All interviews were transcribed completely, and qualitative text analysis [37] was conducted using MAXQDA software (version 2020) to extract the land use conflicts mentioned in the interviews. This process revealed 149 conflicts that were either ongoing at the time of the interviews or had been settled recently. In some cases, several actors named the same conflict. Information regarding these identical conflicts was combined, resulting in 124 different conflicts. While these conflicts were diverse-some of major importance to the whole region, others involving only a few individuals; some highly escalated, others latent tensions (also see [36])—no further selection was made, as a wider range of conflicts included in the analysis could generate a more comprehensive overview of conflict lines. After all, a conflict that is minor for the whole region might still be extremely important to individual actors, and a latent tension between rural and urban actors supports the narrative of an urban-rural dichotomy just as much as an open conflict.

Then, the qualitative text analysis was continued, and the spatial patterns of the conflict lines were coded for each conflict. The spatial affiliations of the involved actors were determined through a deductive-inductive process, with "city", "fringe", and "rural areas outside the fringe" being pre-existing categories deducted from the research design. Further categories were added inductively during the coding process as necessary, whenever actors that were not predominantly affiliated with any of the existing categories emerged. In the first step, new categories were coded using the original words of the interview partners and, in the second step, the new codes were clustered. Each actor's affiliation with a category was determined either by their location (i.e., residents of a category or businesses operating within it) or by their representation of the interests of that category (i.e., mayors representing the interests of fringe communities, agencies representing the interests of the federal government). In a few conflicts, some of the actors involved were affiliated equally with the city and with the fringe (i.e., a local board that is responsible for the whole region). As this was considered an interesting aspect, these actors were coded as a separate category called "city and fringe". Any actors for whom the predominant affiliation could not be unequivocally determined were clustered in the category "unclear". Importantly, one conflict could have more than one conflict line; for example, a city actor could be in conflict with a fringe actor but also with an actor from another country. In this context, it was also noted whether a conflict involved an alliance of actors from the city of Schwerin with actors from its fringe. All categories and their coding rules are listed in Table 1 . The complete results of the qualitative text analysis are provided in Table S1: Results of the text analysis in the Supplementary Materials. 
Table 1. Categories of spatial affiliations, with coding rules and examples.

\begin{tabular}{|c|c|c|c|c|}
\hline & & Spatial Affiliation & Explanation/Criteria & Examples \\
\hline \multirow{7}{*}{$\begin{array}{l}\text { Deductive categories from the } \\
\text { research design }\end{array}$} & \multirow{3}{*}{ Urban } & \multirow{3}{*}{ City of Schwerin } & $\begin{array}{l}\text { Actors predominantly affiliated } \\
\text { with the city of Schwerin: }\end{array}$ & \\
\hline & & & $\begin{array}{l}\text { - Representing the interests of } \\
\text { the city }\end{array}$ & $\begin{array}{ll}- & \text { Mayor } \\
- & \text { City's administration }\end{array}$ \\
\hline & & & $\begin{array}{l}\text { - Located or operating } \\
\text { predominantly within the } \\
\text { city }\end{array}$ & $\begin{array}{ll}-\quad & \text { Businesses } \\
\text { Residents of the city }\end{array}$ \\
\hline & \multirow{4}{*}{ Rural } & \multirow{3}{*}{ Fringe } & $\begin{array}{l}\text { Actors predominantly affiliated } \\
\text { with the rural fringe: }\end{array}$ & \\
\hline & & & $\begin{array}{l}\text { Representing the interests of } \\
\text { fringe communities }\end{array}$ & $\begin{array}{ll}- & \text { Mayors } \\
\text { - } & \text { District administrations }\end{array}$ \\
\hline & & & $\begin{array}{l}\text { - Located or operating } \\
\text { predominantly within the } \\
\text { fringe }\end{array}$ & $\begin{array}{ll}- & \text { Farms } \\
- & \text { Businesses } \\
- & \text { Residents of the fringe }\end{array}$ \\
\hline & & $\begin{array}{l}\text { Adjacent rural areas outside } \\
\text { fringe }\end{array}$ & $\begin{array}{l}\text { Actors predominantly affiliated } \\
\text { with adjacent rural areas }\end{array}$ & $\begin{array}{ll}- & \text { Farms } \\
- & \text { Businesses } \\
- & \text { Residents of rural areas }\end{array}$ \\
\hline \multirow{10}{*}{$\begin{array}{l}\text { Inductive categories created } \\
\text { during coding }\end{array}$} & \multirow{10}{*}{ Other } & City and fringe & $\begin{array}{l}\text { Actors affiliated equally with the } \\
\text { city and the rural fringe }\end{array}$ & $\begin{array}{l}\text { - } \quad \text { Local boards } \\
\text { Group of residents from both } \\
\text { the city and the fringe }\end{array}$ \\
\hline & & $\begin{array}{l}\text { Mecklenburg- Western } \\
\text { Pomerania (MWP) }\end{array}$ & $\begin{array}{c}\text { Actors predominantly affiliated } \\
\text { with the entire federal state of } \\
\text { MWP }\end{array}$ & $\begin{array}{l}\text { - } \quad \text { State agencies of MWP } \\
\text { Companies operating in the } \\
\text { entire state }\end{array}$ \\
\hline & & Federal Republic of Germany & $\begin{array}{c}\text { Actors predominantly affiliated } \\
\text { with the entire Federal Republic of } \\
\text { Germany }\end{array}$ & - $\quad$ Federal agencies \\
\hline & & European Union (EU) & $\begin{array}{l}\text { Actors predominantly affiliated } \\
\text { with the European Union }\end{array}$ & - $\quad$ European Commission \\
\hline & & Other city & $\begin{array}{l}\text { Actors predominantly affiliated } \\
\text { with a city other than Schwerin }\end{array}$ & $\begin{array}{ll}- & \text { Mayors of other cities } \\
- & \text { Administrations of other cities } \\
-\quad & \text { Businesses } \\
\text { Residents of other cities }\end{array}$ \\
\hline & & Other fringe & $\begin{array}{c}\text { Actors predominantly affiliated } \\
\text { with the rural fringe of another } \\
\text { city }\end{array}$ & $\begin{array}{l}\text { - Mayors of communities within } \\
\text { the fringe of another city } \\
\text { District administrations of } \\
\text { other areas }\end{array}$ \\
\hline & & Other rural areas & $\begin{array}{l}\text { Actors predominantly affiliated } \\
\text { with rural areas adjacent to the } \\
\text { fringe of another city }\end{array}$ & $\begin{array}{ll}- & \text { Farms } \\
- & \text { Businesses } \\
- & \text { Residents of rural areas }\end{array}$ \\
\hline & & Other city and fringe & $\begin{array}{l}\text { Actors affiliated equally with } \\
\text { another city and its rural fringe }\end{array}$ & $\begin{array}{l}\text { Group of residents from both } \\
\text { the city and the fringe }\end{array}$ \\
\hline & & International & $\begin{array}{l}\text { Actors predominantly affiliated } \\
\text { with individual EU countries or } \\
\text { countries outside the EU }\end{array}$ & $\begin{array}{l}\text { - Consumers/producers in } \\
\text { non-EU countries }\end{array}$ \\
\hline & & Unclear & $\begin{array}{l}\text { Actors for whom the predominant } \\
\text { affiliation could not be } \\
\text { determined, or unclear actors }\end{array}$ & $\begin{array}{l}\text { - } \quad \text { Unspecified investors } \\
\text { - } \quad \text { Unidentified actors }\end{array}$ \\
\hline
\end{tabular}

\section{Results}

The results showed that the presumed dichotomy between urban and rural areas is reflected in the empirical data only to a limited extent. On the one hand, urban-versusrural was a frequent and important conflict line; thus, an urban-rural dichotomy was recognizable. On the other hand, however, the majority of conflicts did not involve an urban-rural conflict line; this finding emphasizes that the overall picture is more diverse 
than the urban-versus-rural narrative suggests. In the following sections, the results are presented in detail.

\subsection{Urban-Rural Conflict}

Urban-rural conflict does play a role in the study region, as urban-versus-fringe was the most common conflict line detected. In 48 of the 124 conflicts analyzed, actors who were predominantly affiliated with the city of Schwerin and actors who were predominantly affiliated with its fringe were on opposing sides. These conflicts most frequently centered on questions of settlement development, particularly in relation to how much construction of new housing was allowed in fringe communities (also see Table 2). As the number of residents has much influence on communities' revenue, and demand for housing in the fringe is high, developing new housing areas is the most promising way to generate higher revenue for many fringe communities. However, the city competes for residents with fringe communities, and the issue has become a delicate topic. In line with the often-cited urban-versus-rural narrative, communities in the fringe feel disadvantaged, as the city aims to restrict their development and is favored by German planning law. Furthermore, environmental/species conservation, infrastructures, and recreational/touristic land uses are prominent conflict issues between fringe and city actors. For example, ecological compensation areas, which are required by German planning law to compensate for the environmental impacts of new construction, are a frequent cause of dissent between the fringe and the city. The city of Schwerin lacks the space to provide compensation areas for its own construction projects within its limits and therefore depends on space in the fringe communities. However, as land used for ecological compensation areas is normally lost to other land uses, such as agriculture or construction, and thus decreases in economic value, fringe actors often perceive compensation areas as a burden. These conflicts also align well with the common narrative, as actors in the fringe do have to bear the negative consequences of development within the city.

Table 2. Contested land uses in conflicts with an urban-fringe conflict line ${ }^{1}$.

\begin{tabular}{cc}
\hline Contested Land Uses & Number of Conflicts \\
\hline Housing & 17 \\
\hline Environmental/species conservation & 9 \\
\hline Infrastructures (energy/traffic) & 9 \\
\hline Recreational/touristic land uses & 9 \\
\hline Agricultural land uses & 4 \\
\hline Forestry & 3 \\
\hline Industry/retail & 3 \\
\hline
\end{tabular}

${ }^{1}$ One conflict can involve more than one contested land use.

In contrast, conflicts between the city of Schwerin and the rural areas outside the direct fringe were rare. This constellation was found in only two conflicts. One was about ecological compensation areas for construction within the city of Schwerin, similar to the conflicts over compensation areas described above. The other was about parking lots in the city that are used by commuters from both the fringe and communities outside the fringe. As space in the city center is scarce, there is competition between commuters and city dwellers for parking lots but also between parking lots and other land uses, such as for moving traffic. The low number of conflicts between the city and the rural areas outside the fringe might be influenced by the focus on the fringe during data collection; however, the contrast with the high number of city-fringe conflicts is still striking and supports the initial assumption of this study that spatial proximity increases the likelihood of conflicts.

Interestingly, more conflicts were detected between rural areas outside the direct fringe and cities other than Schwerin, even though other cities were not the focus of the 
interviews. This was the case for a total of five conflict lines. This may have been because most other towns in the region do not have an official fringe. In these cases, the analytical categories "rural areas outside the fringe" and "city" border each other directly, and this spatial proximity might have increased the number of conflicts.

\subsection{Other Conflict Lines}

Despite the relatively high number of city-fringe conflicts, the results of this analysis underline that urban-rural conflict is not the dominant element in land use conflicts in the study region. More than half of all conflicts did not involve an urban-rural conflict line. Instead, actors from the city of Schwerin, from its fringe, and from rural areas outside the fringe were frequently in conflict with actors with the same spatial affiliation; this finding further strengthens the idea that spatial proximity plays a role in land use conflicts. In 44 conflicts, a fringe-versus-fringe conflict line was detected; in 22 conflicts, a city-versus-city conflict line was detected; and in 10 conflicts, a conflict line within the rural areas outside the fringe was detected. After city-versus-fringe conflict lines, these were the next most common conflict lines.

Fringe-versus-fringe conflicts most frequently concerned the construction of infrastructures for traffic or renewable energy (see Table 3). In addition to negative impacts on local residents due to noise or visual blight, infrastructure projects are controversial because they lead to a loss of agricultural land. This is particularly problematic because agricultural land is also under pressure from housing development and environmental conservation efforts (as described in Section 3.1). Additionally, residents of the fringe repeatedly protested against nuisances caused by agricultural facilities, such as odor, pollution, and traffic. As Schwerin's fringe is shaped by large-scale agriculture that is spatially intertwined with housing areas, this might come as little surprise. Farmers, in turn, felt that local residents had no appreciation for agriculture. Interestingly, these conflicts are in line with the urban-rural conflict narrative, which holds city dwellers accountable for nuisances and infrastructure development. However, this point was rarely raised in the interviews describing these conflicts. Instead, the conflict lines appeared between residents and local business owners, developers, or farmers, sometimes involving the administrations that regulate the issue in question or foreign investors, as described in more detail below.

Table 3. Contested land uses in conflicts with a fringe-fringe conflict line ${ }^{1}$.

\begin{tabular}{cc}
\hline Contested Land Uses & Number of Conflicts \\
\hline Infrastructures (energy/traffic) & 15 \\
\hline Agricultural land uses & 10 \\
\hline Environmental/species conservation & 8 \\
\hline Recreational/touristic land uses & 5 \\
\hline Housing & 5 \\
\hline Land uses for water/waterbody management & 4 \\
\hline Forestry & 3 \\
\hline Industry/retail & 1 \\
\hline
\end{tabular}

${ }^{1}$ One conflict can involve more than one contested land use.

City-versus-city conflicts most often concerned the development of traffic infrastructure within the city, with land users opposed to the loss of land and residents concerned about increased traffic volumes (also see Table 4). For example, the construction of a bike lane along Schwerin's lake shore caused residents to mobilize because they did not want to lose private access to the lake and were worried about noise nuisance. While conflicts about housing were much more frequent in the fringe, they were still the second-most important issue in the city. Here, construction of housing, among other issues, endangered 
a fresh air corridor, causing a conflict between the climate change management of the city and plans to provide more housing.

Table 4. Contested land uses in conflicts with an urban-urban conflict line ${ }^{1}$.

\begin{tabular}{cc}
\hline Contested Land Uses & Number of Conflicts \\
\hline Infrastructures (energy/traffic) & 7 \\
\hline Housing & 5 \\
\hline Recreational/touristic land uses & 4 \\
\hline Environmental/species conservation & 3 \\
\hline Forestry & 2 \\
\hline Agricultural land uses & 2 \\
\hline Industry/retail & 1 \\
\hline Land uses for water/waterbody management & 1 \\
\hline
\end{tabular}

${ }^{1}$ One conflict can involve more than one contested land use.

Conflicts within the rural areas outside the fringe were frequently shaped by land use competition between different sectors, such as housing, industry, agriculture, and tourism, and were relatively evenly distributed over the different land use types (see Table 5). For example, a new industrial park in a rural community led to a series of conflicts because it increased traffic volumes and demand for housing and was located inside a biosphere reserve, threatening the region's recreational value. Similar to the conflicts around agricultural land uses in the fringe, residents of the rural areas farther away from the city also complained about nuisances caused by agriculture, such as odor and flies. In addition, the loss of agricultural land due to the construction of infrastructure or housing, as well as compensation measures for construction projects in rural communities, appeared repeatedly in conflicts outside the fringe.

Table 5. Contested land uses in conflicts with conflict lines within the rural areas outside the fringe ${ }^{1}$.

\begin{tabular}{cc}
\hline Contested Land Uses & Number of Conflicts \\
\hline Industry/retail & 4 \\
\hline Agricultural land uses & 4 \\
\hline Infrastructures (energy/traffic) & 2 \\
\hline Environmental/species conservation & 2 \\
\hline Housing & 2 \\
\hline Recreational/touristic land uses & 1 \\
\hline
\end{tabular}

${ }^{1}$ One conflict can involve more than one contested land use.

Furthermore, many other actor constellations appeared that involved actors from other regions or other administrative levels, such as the whole state of Mecklenburg-Western Pomerania or the Federal Republic of Germany. Actors from the city of Schwerin, its fringe, and adjacent rural areas outside the fringe were in conflict with actors from other regions or administrative levels on 23 occasions (see Table 6 for an overview of the contested land uses in these conflicts). Most often, this involved land uses for infrastructures or environmental/species conservation. For example, local residents opposed to the construction of energy infrastructure often directed their protest at the federal government for its efforts to expand renewables. Investors from other states, or even foreign countries, were also repeatedly involved in these conflicts. Farmers, on the other hand, complained that the European Union's Common Agricultural Policy's incentives sometimes undermined environmental conservation efforts. For instance, according to some interviewees, environmentally valuable flowered areas have to be plowed every four years to maintain their 
status as arable land and for the farmers to continuously receive subsidies for them; this was a requirement that many farmers found illogical. In total, 22 different types of spatial conflict lines were identified, excluding conflict lines that involved an "unclear" party. Interestingly, actors from the fringe were by far the most frequently involved in conflict lines, being participants in 126 of the 178 individual conflict lines. For an overview of all the conflict lines, as well as their frequencies, see Table A1 in the Appendix A.

Table 6. Contested land uses in conflicts with a conflict line between actors affiliated with the study region and actors affiliated with other regions or administrative levels ${ }^{1}$.

\begin{tabular}{cc}
\hline Contested Land Uses & Number of Conflicts \\
\hline Infrastructures (energy/traffic) & 8 \\
\hline Environmental/species conservation & 8 \\
\hline Agricultural land uses & 5 \\
\hline Recreational/touristic land uses & 2 \\
\hline Housing & 1 \\
\hline Industry/retail & 1 \\
\hline
\end{tabular}

${ }^{1}$ One conflict can involve more than one contested land use.

Finally, actors from the city of Schwerin and actors from its fringe also formed alliances. This was the case in 15 of the analyzed conflicts. For example, both the city of Schwerin and communities on its fringe would like to develop touristic infrastructure in the region, but they repeatedly come into conflict with environmental conservation interests. Thus, a passenger ship line that would have connected touristic sites in Schwerin with sites in a fringe community could not be established because of environmental concerns regarding the construction of a new dock. Such issues are common in the region because its high natural value attracts tourism but also carries environmental obligations. Moreover, another 15 conflicts involved actors or actor groups that were equally affiliated with the city of Schwerin and its fringe. For instance, a loose group of water sports enthusiasts from the whole region who are in favor of lenient rules for navigation is in conflict with conservationists, who are worried about the impacts of water sports on endangered species. Thus, in a total of 30 conflicts, actors from the city of Schwerin and actors from its fringe appeared on the same side, which further calls into question the idea of an urban-rural dichotomy in land use conflicts. For the complete results of the text analysis, with conflict lines and city-fringe alliances marked for each conflict, refer to Table S1: Results of the text analysis in the Supplementary Materials.

It is, however, important to note that, for a few conflicts, there was too little information available to identify the spatial affiliations of all the conflict parties. This was the case for ten conflict lines in which at least one actor whose spatial affiliation remained unclear was mentioned by the interviewees. Thus, some uncertainty remains, even though ten additional conflict lines do not negate the trends that were apparent in the other results.

\section{Discussion}

The results presented above confirm the hypothesis of this paper: that the narrative of the dichotomous land use interests of city and rural areas is to some degree reflected in the empirical data but, overall, the conflict lines are much more complex. Both rural and urban actors are diverse and have manifold and often contradictory land use interests among themselves $[18,20]$. Land use interests frequently span spatial entities and are linked less to each actor's affiliation with urban or rural areas and more to their specific tasks and goals, as well as to their values and beliefs more broadly (also see Sinus-Milieus: [38]). This is consistent with the results of Salka, who found urban-rural conflicts regarding environmental policy in the Western United States but discovered that preferences were related more to diverging socioeconomic variables than to the urban or rural nature of a 
county [16]. Furthermore, in a world where land use interests can be interlinked across large distances (see, for example, [39]), actors from other regions also play an important role in local conflicts.

The findings of this paper therefore add empirical evidence to the broader debate about the urban-rural dichotomy (see [40] for a summary). In line with the results of previous studies on conflicts in specific land use sectors (i.e., [14,15]), the results of this study confirm that urban-rural conflicts exist and show that these conflicts play a significant role, particularly within fringe areas. Even "typical" elements of the urban-rural narrative, such as rural communities being at a disadvantage compared to cities, and that they bear the negative consequences of development in cities, were recognizable in some of the conflicts. Thus, engaging with urban-rural conflict is important. Nevertheless, an urbanrural dichotomy lens alone would have missed the majority of the conflicts discovered in this study. While it can be useful to describe the lines in certain conflicts, the dichotomy narrative should be applied cautiously.

This is relevant to consider in landscape governance. Scholars have emphasized that land use conflicts are an essential element of democratic processes and serve as drivers of change [41,42]. However, to exploit these positive functions and prevent conflicts from becoming barriers to sustainable land management, they first need to be recognized. Preconceived ideas of typical conflict lines could interfere with this and lead to some conflicts being overlooked. Hence, the results also highlight the necessity of empirically analyzing actors, their interests, and coalitions, as has previously been stressed in the literature on conflict analysis (i.e., [23-26]). Approaches that attempt to balance the interests of urban and rural actors (see $[43,44]$ ) are useful steps toward sustainable landscape governance in urban-rural fringe regions, as the significant number of urban-rural conflicts detected in this study confirms. However, by themselves, such approaches are not sufficient. Instead, developing landscape governance tools that balance the interests of multiple land use sectors and of social groups with diverging values is just as necessary.

Moreover, the findings of this paper suggest some tentative generalizations regarding where land use conflicts in urban-rural fringe regions tend to occur. First, despite the presence of some conflict lines involving other regions, spatial proximity appears to play a role in land use conflicts. This is suggested by the relatively few conflicts between city and rural areas outside the direct fringe, the slightly higher number of conflicts between nonfringe communities and cities without an official fringe, and the numerous conflicts within spatial entities. This finding also matches previous results by Darkoh and Mbaiwa [27] and Steinhäußer et al. [29] that showed that stakeholder groups seem to frequently come into conflict among themselves. Apparently, this is true not only when stakeholders are grouped by land use sector but also when they are grouped according to their spatial affiliations. Second, and in line with the initial assumptions of this study, urban-rural fringes indeed appear to be prone to land use conflicts. The findings that the fringe was involved in most conflicts, and that fringe-versus-fringe was the most common conflict line after city-versus-fringe, confirm this idea; these trends likely emerged because of the fringe's multifunctionality and its complex actor constellations $[5,40]$.

\subsection{Limits}

The results presented here were obtained through a single case study of one urbanrural fringe region; therefore, their applicability to other regions remains uncertain. However, the case study region was carefully selected on the basis of its typical urban-rural fringe features; thus, similar results for other urban-rural fringe regions seem probable. Furthermore, a complete conflict analysis of each conflict that integrated the views of all involved actors would have been desirable, as different actors might perceive conflict lines differently. However, due to time constraints, conducting a complete conflict analysis of each of the 124 conflicts that emerged was not feasible. To answer the research question and obtain a comprehensive picture of the conflict lines in the study region, it was considered more important to aim for a relatively complete overview of the region's most important 
conflicts than to analyze only a few conflicts in detail. Thus, the conflict lines are depicted here as they were described by key actors in the region. Nevertheless, as these actors were all experts in the land use questions in the region, and were usually knowledgeable about the different parties' positions, their account of the conflicts likely conveyed the conflict lines with a satisfactory level of accuracy.

\subsection{Implications for Future Research}

Accounting for these limits, we consider the results presented here to be preliminary, and we encourage further research to substantiate them. In particular, it would be interesting to determine directly how actors who are involved in conflicts perceive them: Do they experience these conflicts as urban-rural issues? Perhaps they see them as administrative conflicts, or simply as conflicts between individuals? Furthermore, quantitative research determining which topics tend to produce urban-rural conflicts and which topics are shaped more by other conflict lines would add important insights. Hence, we believe that communicating these preliminary findings is of interest to the debate around urban-rural conflicts, to other scholars planning research on the topic, and to the field of landscape governance.

\section{Conclusions}

This paper shows that the urban-rural dichotomy is an important element of conflict lines in the urban-rural fringe region of Schwerin. However, it also shows that, overall, these conflicts are more diverse than the urban-versus-rural narrative would suggest. The majority of conflict lines run within or across spatial units or involve actors from other regions and other administrative levels. Thus, the dichotomy narrative must be applied only cautiously to land use conflicts in urban-rural fringe regions. This paper therefore emphasizes that it is important to determine actor constellations in land use conflicts empirically rather than relying on existing ideas of common conflict lines. It also adds empirical evidence to the debate around the urban-rural dichotomy. Finally, this paper contributes information to the landscape governance sector, as an awareness of the diversity of conflict lines is a precondition for developing appropriate tools to balance the manifold demands and pressures that landscapes experience.

Supplementary Materials: The following are available online at https:/ /www.mdpi.com/article/10 .3390/land10070726/s1, Document S1: Interview guideline, Table S1: Results of the text analysis.

Author Contributions: Conceptualization, M.F. and R.S.; methodology, M.F. and R.S.; validation, M.F.; formal analysis, M.F.; investigation, M.F.; data curation, M.F.; writing-original draft preparation, M.F.; writing-review and editing, M.F. and R.S.; supervision, R.S.; project administration, M.F.; funding acquisition, R.S. All authors have read and agreed to the published version of the manuscript.

Funding: This research was funded by Bundesministerium für Bildung, Wissenschaft und Forschung, grant number 033L205A. The APC was funded by the Open Access Fund of the Leibniz Association.

Institutional Review Board Statement: Not applicable.

Informed Consent Statement: Not applicable.

Acknowledgments: We thank all interview partners who took the time to contribute to this study. We further want to thank Alexandra Gundlach for assistance with the transcription of the interviews and data curation, Alice Baumgärtner for assistance with data curation, and three anonymous reviewers for comments on an earlier draft. We thank the Open Access Fund of the Leibniz Association for funding the publication of this article.

Conflicts of Interest: The authors declare no conflict of interest. 


\section{Appendix A}

Table A1. Number of conflicts where specific conflict lines appeared.

\begin{tabular}{|c|c|}
\hline Conflict Line & Number of Conflicts \\
\hline City versus fringe & 48 \\
\hline Fringe versus fringe & 44 \\
\hline City versus city & 22 \\
\hline Rural (outside fringe) versus rural (outside fringe) & 10 \\
\hline Fringe versus city and fringe & 7 \\
\hline Fringe versus Mecklenburg-Western Pomerania & 6 \\
\hline City and fringe versus city and fringe & 5 \\
\hline Fringe versus Federal Republic of Germany & 5 \\
\hline Rural (outside fringe) versus other city & 4 \\
\hline City versus city and fringe & 3 \\
\hline Fringe versus EU & 2 \\
\hline Rural (outside fringe) versus Federal Republic of Germany & 2 \\
\hline City versus rural (outside fringe) & 2 \\
\hline Other city versus other city & 2 \\
\hline Rural (outside fringe) versus city and fringe & 1 \\
\hline Rural (outside fringe) versus EU & 1 \\
\hline City versus other city & 1 \\
\hline Mecklenburg-Western Pomerania (MWP) versus MWP & 1 \\
\hline City and fringe versus Federal Republic of Germany & 1 \\
\hline Federal Republic of Germany versus Federal Republic of Germany & 1 \\
\hline Other city and fringe versus other fringe & 1 \\
\hline Other city and fringe versus rural (outside fringe) & 1 \\
\hline
\end{tabular}

\section{References}

1. Sholanke, A.B.; Opoko, A.P.; Yakubu, P.O.; Ukwedeh, J.O. Effects and Resolution Guidelines of Land use Conflict in Construction Management in Lagos State, Ni-Geria. Int. J. Innov. Technol. Explor. Eng. 2019, 8, 2008-2013.

2. Toth, G.; Huzui-Stoiculescu, A.; Toth, A.-I.; Stoiculescu, R. How Do Natura 2000 Areas Intersect with Peoples' Livelihood Strategies in High Nature Value Farmlands in Southern Transylvania? Land 2020, 9, 484. [CrossRef]

3. Petrişor, A.-I.; Hamma, W.; Nguyen, H.D.; Randazzo, G.; Muzirafuti, A.; Stan, M.-I.; Tran, V.T.; Aştefănoaiei, R.; Bui, Q.-T.; Vintilă, D.-F.; et al. Degradation of Coastlines under the Pressure of Urbanization and Tourism: Evidence on the Change of Land Systems from Europe, Asia and Africa. Land 2020, 9, 275. [CrossRef]

4. Kirschke, D.; Häger, A. New Trends and Drivers for Agricultural Land Use in Germany. In Sustainable Land Management in a European Context: A Co-Design Approach; Weith, T., Barkmann, T., Gaasch, N., Rogga, S., Strauß, C., Zscheischler, J., Schmid, J.C., Eds.; Human-Environment Interactions; Springer International Publishing: Cham, Switzerland, 2021; Volume 8, pp. 39-61, ISBN 978-3-030-50840-1.

5. von der Dunk, A.; Grêt-Regamey, A.; Dalang, T.; Hersperger, A.M. Defining a Typology of Peri-Urban Land use Conflicts-A Case Study from Switzerland. Landsc. Urban Plan. 2011, 101, 149-156. [CrossRef]

6. Bobo, K.S.; Weladji, R.B. Wildlife and Land Use Conflicts in the Mbam and Djerem Conservation Region, Cameroon: Status and Mitigation Measures. Hum. Dimens. Wildl. 2011, 16, 445-457. [CrossRef]

7. Sze, M.N.M.; Sovacool, B.K. Of Fast Lanes, Flora, and Foreign Workers: Managing Land Use Conflicts in Singapore. Land Use Policy 2013, 30, 167-176. [CrossRef]

8. Sinthumule, N.I.; Ratshivhadelo, T.; Nelwamondo, T. Stakeholder Perspectives on Land use Conflicts in the South African Section of the Greater Mapungubwe Transfrontier Conservation Area. J. Land Use Sci. 2020, 15, 11-24. [CrossRef]

9. Reimer, J. Kritischer Agrarbericht: Konflikt Zwischen Stadt Und Land. Deutschlandfunk, 16 January 2020. 
10. Scheller, H. Stadt-Land Konflikt: Stadt Und Land Dürfen Nicht Gegeneinander Ausgespielt Werden. Tagesspiegel, 20 February 2017.

11. Yu, A.T.W.; Wu, Y.; Zheng, B.; Zhang, X.; Shen, L. Identifying Risk Factors of Urban-Rural Conflict in Urbanization: A Case of China. Habitat Int. 2014, 44, 177-185. [CrossRef]

12. Yu, A.T.W.; Wu, Y.; Shen, J.; Zhang, X.; Shen, L.; Shan, L. The Key Causes of Urban-Rural Conflict in China. Habitat Int. 2015, 49, 65-73. [CrossRef]

13. Shan, L.; Yu, A.T.W.; Wu, Y. Strategies for Risk Management in Urban-Rural Conflict: Two Case Studies of Land Acquisition in Urbanising China. Habitat Int. 2017, 59, 90-100. [CrossRef]

14. Sukhwani, V.; Thapa, K.; Shaw, R.; Deshkar, S.; Mitra, B.K.; Yan, W. Addressing Urban-Rural Water Conflicts in Nagpur through Benefit Sharing. Water 2020, 12, 2979. [CrossRef]

15. Salhi, A.; Benabdelouahab, S.; Bouayad, E.O.; Benabdelouahab, T.; Larifi, I.; El Mousaoui, M.; Acharrat, N.; Himi, M.; Casas Ponsati, A. Impacts and Social Implications of Landuse-Environment Conflicts in a Typical Mediterranean Watershed. Sci. Total Environ. 2021, 764, 142853. [CrossRef]

16. Salka, W.M. Urban-Rural Conflict over Environmental Policy in the Western United States. Am. Rev. Public Adm. 2000, 31, 33-48. [CrossRef]

17. Ayele, A.; Tarekegn, K. The Impact of Urbanization Expansion on Agricultural Land in Ethiopia: A Review. Environ. Socio-Econ. Stud. 2020, 8, 73-80. [CrossRef]

18. Scott, K.; Park, J.; Cocklin, C. From 'sustainable Rural Communities' to 'social Sustainability': Giving Voice to Diversity in Mangakahia Valley, New Zealand. J. Rural Stud. 2000, 16, 433-446. [CrossRef]

19. Hodge, I.; Monk, S. The Economic Diversity of Rural England: Stylised Fallacies and Uncertain Evidence. J. Rural Stud. 2004, 10, 263-272. [CrossRef]

20. Hamelink, C.J. Urban Conflict and Communication. Int. Commun. Gaz. 2008, 70, 291-301. [CrossRef]

21. Seto, K.C.; Reenberg, A.; Boone, C.G.; Fragkias, M.; Haase, D.; Langanke, T.; Marcotullio, P.; Munroe, D.K.; Olah, B.; Simon, D. Urban Land Teleconnections and Sustainability. Proc. Natl. Acad. Sci. USA 2012, 109, 7687-7692. [CrossRef] [PubMed]

22. Schaeffer, P.V.; Kahsai, M.S.; Randall, W.J. Beyond the Rural-Urban Dichotomy: Essay in Honor of Professor A. M. Isserman. Int. Reg. Sci. Rev. 2013, 36, 81-96. [CrossRef]

23. Grimble, R.; Wellard, K. Stakeholder Methodologies in Natural Resource Management: A Review of Principles, Contexts, Experiences and Opportunities. Agric. Syst. 1997, 55, 173-193. [CrossRef]

24. Ramirez, R. Stakeholder analysis and conflict management. In Cultivating Peace: Conflict and Collaboration in Natural Resource Management; IDRC, Ed.; IDRC: Ottawa, ON, Canada, 1999; pp. 101-126.

25. Davies, A.L.; Bryce, R.; Redpath, S.M. Use of Multicriteria Decision Analysis to Address Conservation Conflicts: Multicriteria Decision Analysis. Conserv. Biol. 2013, 27, 936-944. [CrossRef]

26. Nolon, S.; Ferguson, O.; Field, P. Land in Conflict: Managing and Resolving Land Use Disputes; Lincoln Institute of Land Policy: Cambridge, MA, USA, 2013; ISBN 978-1-55844-246-7.

27. Darkoh, M.B.K.; Mbaiwa, J.E. Land use and Resource Conflicts in the Okavango Delta, Botswana. Afr. J. Ecol. 2009, 47, 161-165. [CrossRef]

28. Abegunde, V.O.; Alawode, O.O.; Sibanda, M. Socioeconomic Impact of Land Use Conflict: A Study of Agricultural Production in Southwest Nigeria. Niger. J. Econ. Soc. Stud. 2020, 62, 127-146.

29. Steinhäußer, R.; Siebert, R.; Steinführer, A.; Hellmich, M. National and Regional Land use Conflicts in Germany from the Perspective of Stakeholders. Land Use Policy 2015, 49, 183-194. [CrossRef]

30. Darly, S.; Torre, A. Conflicts over Farmland Uses and the Dynamics of "Agri-Urban" Localities in the Greater Paris Region: An Empirical Analysis Based on Daily Regional Press and Field Interviews. Land Use Policy 2013, 33, 90-99. [CrossRef]

31. Hjalager, A.-M. Land use Conflicts in Coastal Tourism and the Quest for Governance Innovations. Land Use Policy 2020, 94, 104566. [CrossRef]

32. Stead, D. Urban-Rural Relationships in the West of England. Built Environ. 2002, 28, 299-310.

33. Lamnek, S.; Krell, C. Qualitative Sozialforschung: Lehrbuch; 5. überarbeitete Auflage; Beltz: Weinheim, Germany; Basel, Switzerland, 2010; ISBN 978-3-621-27770-9.

34. Benjaminsen, T.A.; Alinon, K.; Buhaug, H.; Buseth, J.T. Does Climate Change Drive Land use Conflicts in the Sahel? J. Peace Res. 2012, 49, 97-111. [CrossRef]

35. Brown, G.; Raymond, C.M. Methods for Identifying Land Use Conflict Potential Using Participatory Mapping. Landsc. Urban Plan. 2014, 122, 196-208. [CrossRef]

36. Torre, A.; Melot, R.; Magsi, H.; Bossuet, L.; Cadoret, A.; Caron, A.; Darly, S.; Jeanneaux, P.; Kirat, T.; Pham, H.V.; et al. Identifying and Measuring Land use and Proximity Conflicts: Methods and Identification. SpringerPlus 2014, 3, 85. [CrossRef] [PubMed]

37. Kuckartz, U. Qualitative Text Analysis: A Guide to Methods, Practice E Using Software; Sage: Los Angeles, CA, USA; London, UK; New Delhi, India; Singapore; Washington, DC, USA, 2014; ISBN 978-1-4462-6775-2.

38. SINUS Information on Sinus-Milieus 2015. 2015. Available online: https://www.sinus-institut.de/veroeffentlichungen/ downloads/download/information-on-sinus-milieusR/download-file/354/download-a/download/download-c/Category/ (accessed on 11 May 2021). 
39. Friis, C.; Nielsen, J.Ø.; Otero, I.; Haberl, H.; Niewöhner, J.; Hostert, P. From Teleconnection to Telecoupling: Taking Stock of an Emerging Framework in Land System Science. J. Land Use Sci. 2016, 11, 131-153. [CrossRef]

40. Doernberg, A.; Weith, T. Urban-Rural Interrelations A Challenge for Sustainable Land Management. In Sustainable Land Management in a European Context: A Co-Design Approach; Weith, T., Barkmann, T., Gaasch, N., Rogga, S., Strauß, C., Zscheischler, J., Eds.; Human-Environment Interactions; Springer International Publishing: Cham, Switzerland, 2021; Volume 8, pp. 101-124, ISBN 978-3-030-50840-1.

41. Sebastien, L. From NIMBY to Enlightened Resistance: A Framework Proposal to Decrypt Land use Disputes Based on a Landfill Opposition Case in France. Local Environ. 2017, 22, 461-477. [CrossRef]

42. Gómez-Vázquez, I.; Álvarez-Álvarez, P.; Marey-Pérez, M.F. Conflicts as Enhancers or Barriers to the Management of Privately Owned Common Land: A Method to Analyze the Role of Conflicts on a Regional Basis. For. Policy Econ. 2009, 11, 617-627. [CrossRef]

43. Repp, A.; Weith, T. Building Bridges across Sectors and Scales: Exploring Systemic Solutions towards A Sustainable Management of Land -Experiences from 4th Year Status Conference on Research for Sustainable Land Management. Land 2015, 4, 325-336. [CrossRef]

44. Zhang, X.; Wu, Y.; Skitmore, M.; Jiang, S. Sustainable Infrastructure Projects in Balancing Urban-Rural Development: Towards the Goal of Efficiency and Equity. J. Clean. Prod. 2015, 107, 445-454. [CrossRef] 